\title{
Recurrent cutaneous necrotizing eosinophilic vasculitis: a case report and review of the literature
}

\author{
Wenfei Li ${ }^{1,3}$, Wang Cao ${ }^{3}$, Haiyan Song ${ }^{1}$, Yanxia Ciu' ${ }^{1}$ Xianmei $\mathrm{Lu}^{1,2^{*}}$ and Furen Zhang ${ }^{1,2}$
}

\begin{abstract}
We report a case of recurrent cutaneous necrotizing eosinophilic vasculitis (RCNEV) in a 57-year-old male. The patient presented with papules and pruritus of the lower limbs of more than 1 month duration, and with angioedema and intensively pruritic, necrotizing lesions of the bilateral anterior tibias and feet for 2 weeks. Treatment with systemic corticosteroids was administered for 1 month, and resulted in a significant improvement. We also present a review of the pertinent literature and discuss the clinical features, histopathological features, and differentiation of RCNEV.

Virtual Slides: The virtual slide(s) for this article can be found here: http://www.diagnosticpathology.diagnomx.eu/vs/ 2065600765102207
\end{abstract}

Keywords: Vasculitis, eosinophilic, Recurrent, Ctaneous necrotizing, Corticosteroid

\section{Background}

Recurrent cutaneous necrotizing eosinophilic vasculitis is a rare disease, which has clinical features of annular urticarial plaques, pruritic purpuric papules, angioedema, long course, chronic relapsing process, and an absence of any features of the systemic disease. Histopathological findings of RCNEV show necrotizing vasculitis of dermal small vessels with prominent eosinophilic infiltration. RCNEV was first reported by Chen, in 1994, and to the best of our knowledge there are only five patients with RCNEV described in the literature. Peripheral blood eosinophilia is a feature of many diseases such as hypereosinophilic syndrome, Wells syndrome, ChurgStrauss syndrome, and eosinophilic fasciitis. Compared with the aforementioned diseases, RCNEV has distinct pathological features of fibrinoid degeneration on small vessel walls and necrotizing vasculitis of dermal small vessels with prominent eosinophilic infiltration. Here, we report a case of RCNEV in a 57-year-old male, whose diagnosis was made using clinical, histopathological, and

\footnotetext{
*Correspondence: Xinmeilu2013@163.com

${ }^{1}$ Shandong Provincial Hospital for Skin Diseases, Shandong University, Jinan 250022, China

${ }^{2}$ Shandong Provincial Institute of Dermatology and Venereology, Jinan 250022, China

Full list of author information is available at the end of the article
}

laboratory analysis results, and who was treated using systemic corticosteroids.

\section{Case presentation}

A 57-year-old Chinese male complained of papules and pruritus of the lower limbs for more than 1 month, and angioedema with intensively pruritic, necrotizing lesions of the bilateral anterior tibias and feet for 2 weeks. Several needlepoint-sized papules appeared on his lower limbs, and the patient was treated for "eczema". However, the skin lesions increased, with itchy needlepointto millet-sized papules appearing on the anterior tibias. Three weeks later, lesions of the lower extremities exacerbated, papules merged into purpuric plaques with angioedema, and some lesions became necrotic. Laboratory examinations and a skin biopsy were recommended. He was a farmer, and lived in a small village. He had no history of smoking, drinking and potential exposure to dust. No potential anomalies in nutrition. He did not have a family history of dermatoses, allergic rhinitis, or asthma. He denied a history of insect bites and drug eruption, but had more than five years history of psoriasis. Physical examination showed that necrotizing lesions, plaques of purpuric angioedema, and excoriation were predominantly localized on the lower limbs (Figure 1). He did 


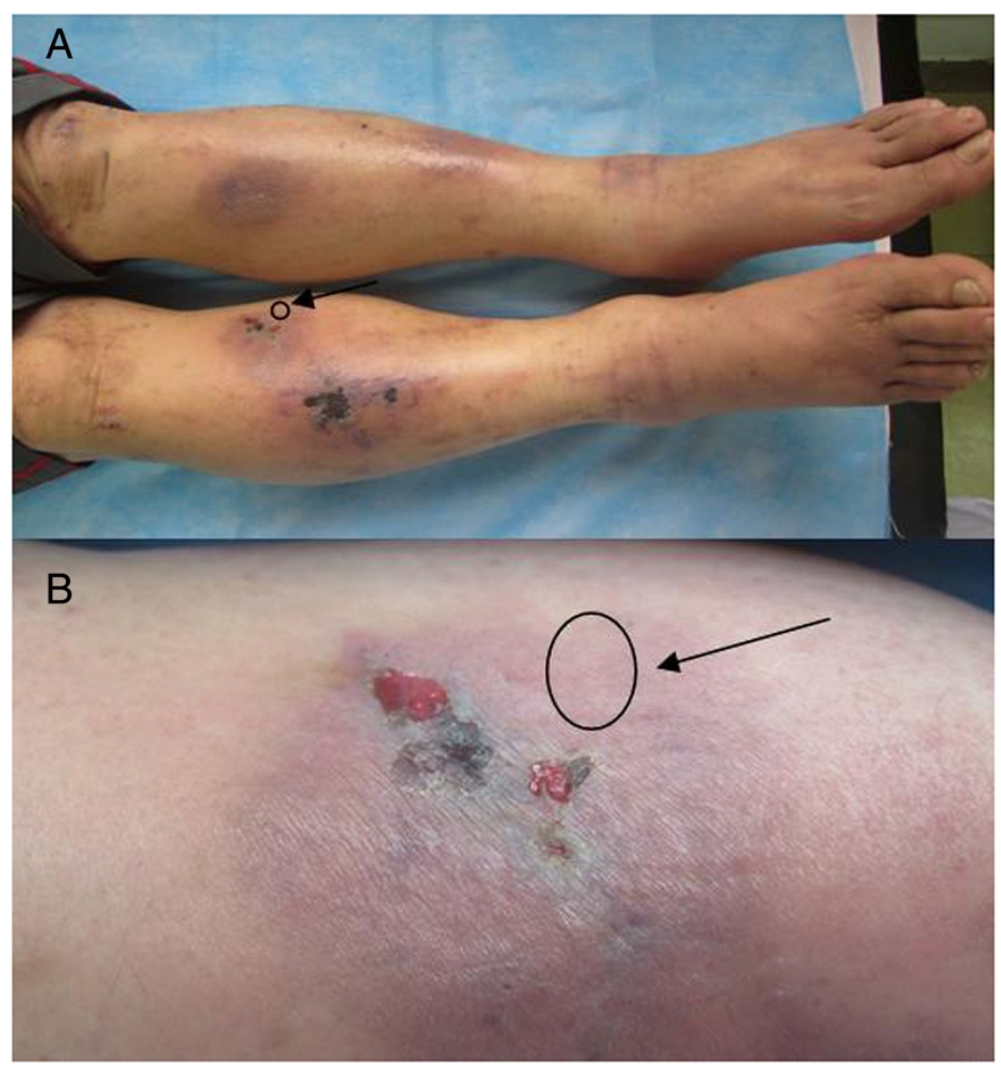

Figure 1 Typical rash showing necrotizing lesions, plaques of purpuric angioedema, and excoriations predominantly localized on the lower limbs. A skin biopsy was performed from the area indicated by the arrow. A: Necrotizing lesions and plaques of purpuric angioedema on the bilateral lower legs and the tops of feet. B: Excoriations on the plaque of purpuric angioedema.

not experience fever or weight loss, and his blood pressure was normal. Electrocardiogram, chest X-ray, abdominal ultrasound, and cranial computed tomography investigations indicated no cardiac, pulmonary, hepatic, splenic, nephritic, central nervous system, maxillary sinus, or other visceral organ involvement.

Additional laboratory analysis revealed: white blood cell count $11.8 \times 10^{9} / 1$ with $28.7 \%$ eosinophils $\left(3.4 \times 10^{9} /\right.$; normal $\left.0.05-0.5 \times 10^{9} / 1\right)$; elevated erythrocyte sedimentation rate $(32 \mathrm{~mm} / \mathrm{h}$; normal $0-15 \mathrm{~mm} / \mathrm{h})$; elevated C-reactive protein level (14.5 mg/1; normal 0-8.2 mg/1); negative antistreptolysin $\mathrm{O}$ titer and rheumatoid factor; elevated serum immunoglobulin E level $(658.3 \mathrm{IU} / \mathrm{ml}$; normal 0-100 IU/ml); normal serum immunoglobulins G, M, and A levels; normal liver enzyme level; abnormal alkaline phosphatase (131 U/l; normal 26-117 U/l); negative anti-neutrophil cytoplasmic antibodies(ANCA; MPO-ANCA $9 \mathrm{Ru} / \mathrm{ml}$; normal 0-20 Ru/ml. PR3-ANCA $7 \mathrm{Ru} / \mathrm{ml}$; normal $0-20 \mathrm{Ru} / \mathrm{ml}$.); negative antinuclear; negative HIV and syphilis antibodies; normal hepatitis A, $\mathrm{B}$, and $\mathrm{C}$ serology; hemolytic complement results consistent with inflammation (C3 $1260 \mathrm{mg} / 1$; normal 900-1800 mg/1, C4 $430 \mathrm{mg} / 1$; normal 100-400 mg/1); normal urine analysis; and stool examinations negative for parasites and ova. A skin biopsy was performed from a purpuric angioedema lesion on the right limb, providing a specimen of about $1.0 \mathrm{~cm} \times 0.5 \mathrm{~cm} \times 0.7 \mathrm{~cm}$. It revealed a normal epidermis and an infiltration consisting of numerous eosinophils and a few neutrophils perivascular, into vessel walls, in the upper and deep dermis, and in the subcutaneous tissue. Thickening of the vessel walls, numerous extravascular erythrocytes, fibrin thrombi in the lumens, and fibrinoid degeneration (Figures 2, 3, 4, 5) were noted. The diagnosis of RCNEV was made.

The patient was initially treated with $1 \mathrm{mg} / \mathrm{kg}$ prednisone daily, compound glycyrrhizin $150 \mathrm{mg}$ daily. $\mathrm{Mu}-$ pirocin ointment was applied to the necrotic lesions. Immediate improvements in clinical manifestations and inflammation were noted. After 2 days, intensive pruritus and angioedema decreased rapidly. After 7 days, pruritus and angioedema had disappeared, and laboratory examinations showed that white blood cell and eosinophil cell count had normalized. One month later, the necrotizing lesions healed, with some remaining as superficial scars. The dose of prednisone was then slowly decreased. All hematological and biochemical examinations were normal and no new lesions were noticed after 4 months of follow-up. As any attempts to discontinue 


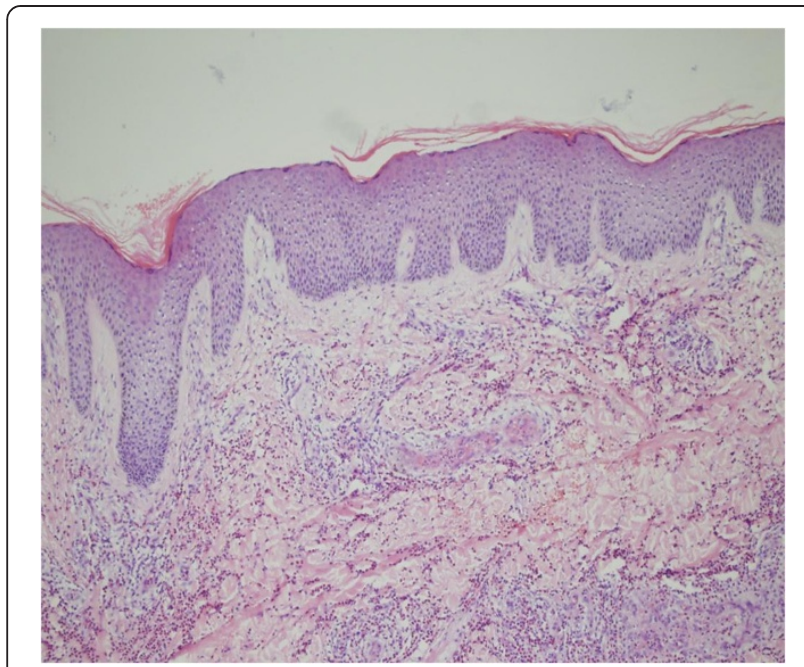

Figure $\mathbf{2}$ Normal epidermis and the infiltration of numerous inflammatory cells in the upper and deep dermis. Thickening of the vessel walls and infiltration of inflammatory cells perivascular and into vessel walls $(H \& E \times 100)$.

prednisone always result in recurrence [1], the patient presently continues to take prednisone at a dose of $10 \mathrm{mg}$ daily.

\section{Discussion}

Chen et al. [2] reported one male and two female patients diagnosed with RCNEV. The male patient, a 17year-old in 1973, noted purpuric lesions on his feet and buttocks, which later involved his entire body. One of the two females was a 56-year-old woman in 1989, and presented with pruritic purpuric lesions of 6-month

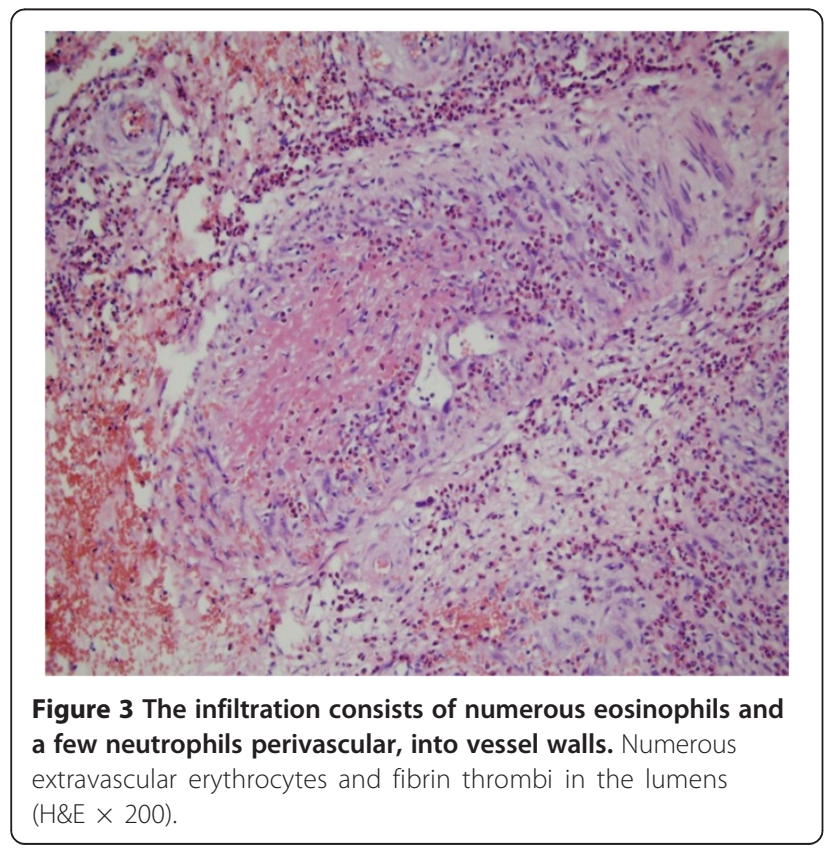

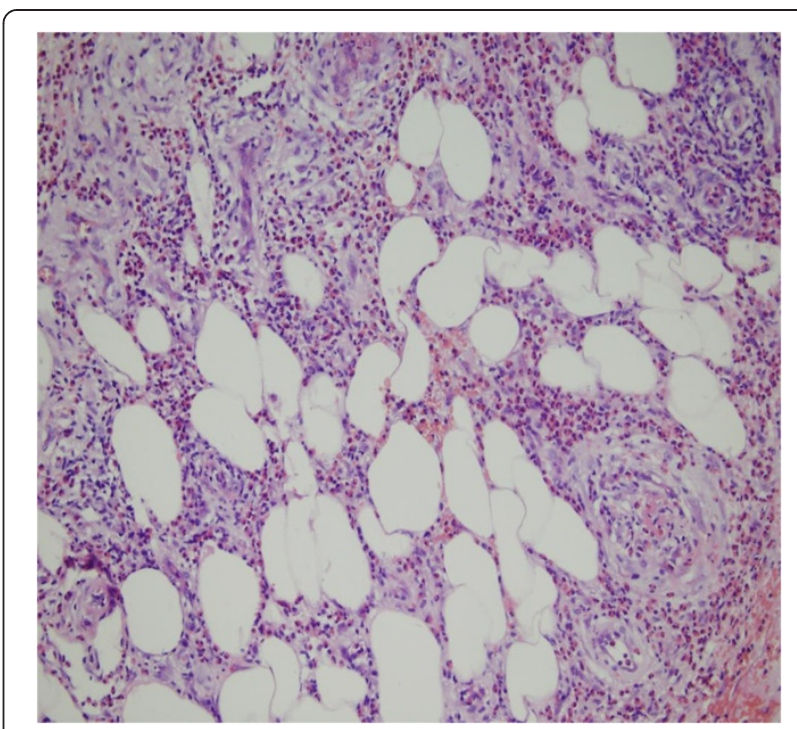

Figure 4 The infiltration consists of numerous eosinophils and a few neutrophils perivascular, into vessel walls, and in the subcutaneous tissue. Numerous extravascular erythrocytes and fibrin thrombi in the lumens $(H \& E \times 200)$.

duration. Another woman, at the age of 18 years in 1967, presented with gingivitis, pruritic, erythematous, and purpuric papules, and angioedema of the hands. Skin biopsy specimens showed a common feature: necrotizing vasculitis with marked perivascular eosinophil infiltration. In 2000, Launay et al. [3] reported one patient who was an 81-year-old woman in 1996 who presented with intensively itchy, infiltrating, necrotic purpuric lesions on the lower limbs for 2 weeks. Skin biopsy was

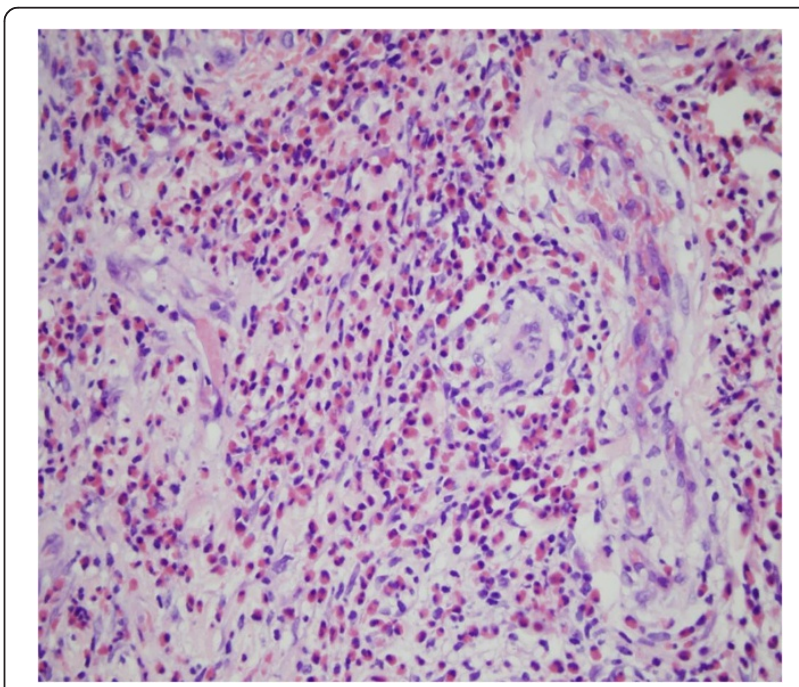

Figure 5 Fibrinoid degeneration and the infiltration consisting of numerous eosinophils and a few neutrophils perivascular and into vessel walls (H\&E $\times 400)$. 
Table 1 Clinicopathological features of HES, Wells syndrome, CSS and EF HES

\begin{tabular}{|c|c|c|c|c|}
\hline & HES & Wells syndrome & CSS & $\mathrm{EF}$ \\
\hline Sex ratio (M:F) & 9.1 & $1: 1$ & $1: 1$ & $2: 1$ \\
\hline Age & $\begin{array}{l}\text { HES can happen at any age, } \\
\text { although it is more common } \\
\text { in adults }\end{array}$ & Wells syndrome usually affects adults & $\begin{array}{l}\text { CSS can present at any age, } \\
\text { with the mean age of onset } \\
\text { being } 40 \text { years }\end{array}$ & $\begin{array}{l}\text { EF usually affects adults } \\
\text { between } 20 \text { and } \\
60 \text { years }\end{array}$ \\
\hline Clinical features & $\begin{array}{l}\text { Skin rashes such as urticaria or } \\
\text { angioedema }\end{array}$ & $\begin{array}{l}\text { Urticaria, cellulitis, annular plaques } \\
\text { vesiculo-bullous lesions and edema }\end{array}$ & $\begin{array}{l}\text { Hypereosinophilia, asthma, } \\
\text { pulmonary infiltrates, and } \\
\text { clinical evidence of vasculitis }\end{array}$ & $\begin{array}{l}\text { Similar to scleroderma or } \\
\text { systemic sclerosis }\end{array}$ \\
\hline $\begin{array}{l}\text { Histopathological } \\
\text { features }\end{array}$ & $\begin{array}{l}\text { Eosinophilic infiltration with } \\
\text { few lymphocytes, perivascular } \\
\text { infiltration in dermis region, } \\
\text { but not true necrotizing } \\
\text { vasculitis }\end{array}$ & $\begin{array}{l}\text { Eosinophilic infiltrates and flame } \\
\text { figures in the absence of vasculitis. } \\
\text { perivascular eosinophilic infiltration in } \\
\text { the dermis, but not true necrotizing } \\
\text { vasculitis }\end{array}$ & $\begin{array}{l}\text { Peripheral blood eosinophils } \\
\text { increase significantly, and } \\
\text { neutrophil-rich leukocytoclastic } \\
\text { vasculitis and granulomatous }\end{array}$ & $\begin{array}{l}\text { Numerous inflammatory } \\
\text { infiltrations of } \\
\text { lymphocytes and } \\
\text { eosinophils within the } \\
\text { fascia }\end{array}$ \\
\hline Treatment & $\begin{array}{l}\text { Prednisone, hydroxyurea, } \\
\text { chlorambucil and vincristine. }\end{array}$ & $\begin{array}{l}\text { Corticosteroids, calcineurin inhibitors, } \\
\text { griseofulvin, H1 antihistamines, } \\
\text { cyclosporine, dapsone }\end{array}$ & $\begin{array}{l}\text { Prednisolone, azathioprine } \\
\text { and cyclophosphamide }\end{array}$ & Prednisone \\
\hline Clinical outcome & $\begin{array}{l}\text { More than } 80 \% \text { of HES } \\
\text { patients survive five years or } \\
\text { more }\end{array}$ & $\begin{array}{l}\text { It tends to resolve in weeks or } \\
\text { months, usually without scarring. It } \\
\text { occasionally recurs. In these recurrent } \\
\text { cases, it can take years to ultimately } \\
\text { resolve }\end{array}$ & $\begin{array}{l}\text { The mean five years mortality } \\
\text { rate is } 28 \%\end{array}$ & $\begin{array}{l}\text { The prognosis is usually } \\
\text { good in the case of an } \\
\text { early treatment if there } \\
\text { is no visceral } \\
\text { involvement }\end{array}$ \\
\hline
\end{tabular}

performed on a necrotizing lesion which showed necrotizing vasculitis in the deep dermis with striking infiltration by eosinophils. In 2007, Tanglertsampan et al. [1] reported a 53-year-old white male diagnosed with RCNEV. He was treated with indomethacin, with a favorable response.

The pathogenesis of RCNEV is not fully understood, but cytotoxic eosinophil granule proteins such as major basic proteins are found to deposit in the areas of blood vessels, suggesting that eosinophils mediate vascular damage in this disease process [3,4]. Eosinophils release IL-5, C4, and platelet-activating factor, which may lead to increased vascular permeability and induce cutaneous lesions such as purpuric papules and angioedema [5,6]. Although he had more than five years history of psoriasis, no evidence confirmed a correlation between psoriasis and RCNEV.

A review of the literature has demonstrated that peripheral blood eosinophilia is related to many dermatoses such as hypereosinophilic syndrome(HES), wells syndrome,or eosinophilic cellulitis, Churg-Strauss syndrome (CSS) and Eosinophilic fasciitis (EF) [7-13]. Clinicopathological features of these diseases are listed in Table 1.

In our case, not only an exclusive clinical histopathological feature of fibrinoid degeneration of small vessel walls, but also necrotizing vasculitis of dermal small vessels with prominent infiltration of eosinophils strongly supported the diagnosis of RCNEV.

With regard to the treatment of RCNEV, systemic corticosteroids are most commonly selected because of their effectiveness. Immediate improvements in clinical manifestations and inflammation were noted in our patient following the administration of prednisone. However, some measures should be taken to avoid its side effects if it is used persistently. Compound glycyrrhizin can reduce the activity of T-lymphocyte subset and play an antiinflammatory role [14]. Mupirocin ointment was used to prevent or control local infection of necrotic lesions. This therapeutic regimen proved to be suitable in our patient, and we consequently obtained a good clinical outcome.

\section{Conclusion}

RCNEV is rare and has clinical and histopathological features, which are different to other conditions of hypereosinophilia and eosinophilic vasculitis. Systemic corticosteroid is very effective in the treatment of RCNEV.

\section{Consent}

Written informed consent was obtained from the patient for publication of this Case Report and any all accompanying images. A copy of the written consent is available for review by the Editor-in-Chief of this journal.

\section{Abbreviations \\ RCNEV: Recurrent cutaneous necrotizing eosinophilic vasculitis; ANCA: Anti-neutrophil cytoplasmic antibodies; MPO: Myeloperoxidase; PR3: Proteinase 3; HES: Hypereosinophilic syndrome; CSS: Churg-Strauss syndrome; EF: Eosinophilic fasciitis.}

\section{Competing interest}

The authors declare that they have no competing interests.

\section{Authors' contributions}

WFL designed the study, performed the histological evaluation, wrote the paper; FRZ and XML participated histological diagnosis; WC was involved in literature search and preparing the material. HYS and YXC participated in providing the clinical information of this case. All authors read and approved the final manuscript. 


\section{Acknowledgements}

We would like to thank Dr. Qun Liu in Qianfoshan Hospital, Shandong University for helping in histological analysis. We also wish to thank International Science Editing, Compuscript Ltd. For editing the manuscript.

\section{Author details}

'Shandong Provincial Hospital for Skin Diseases, Shandong University, Jinan 250022, China. ${ }^{2}$ Shandong Provincial Institute of Dermatology and Venereology, Jinan 250022, China. ${ }^{3}$ Department of Dermatology, Qianfoshan Hospital, Shandong University, Jinan 250014, China.

Received: 20 June 2013 Accepted: 26 October 2013

Published: 7 November 2013

\section{References}

1. Tanglertsampan C, Tantikun N, Noppakun N: Pinyopornpanit V: indomethacin for recurrent cutaneous necrotizing eosinophilic vasculitis. J Med Assoc Thai 2007, 90:1180-1182.

2. Chen KR, Pittelkow MR, Su D, Gleich J, Newman W, Leiferman KM: Recurrent cutaneous necrotizing eosinophilic vasculitis. A novel eosinophil-mediated syndrome. Arch Dermatol 1994, 130:1159-1166.

3. Launay D, Delaporte E, Gillot JM, Janin A, Hachulla E: An unusual cause of vascular purpura: recurrent cutaneous eosinophilic necrotizing vasculitis. Acta Derm Venereol 2000, 80:394-395.

4. Chen KR, Su WP, Pittelkow MR, Conn DL, George T, Leiferman KM: Eosinophilic vasculitis in connective tissue disease. J Am Acad Dermatol 1996, 35(2 Pt 1):173-182.

5. Lee T, Lenihan DJ, Malone B, Roddy LL, Wasserman SI: Increased biosynthesis of platelet-activating factor in activated human eosinophils. J Biol Chem 1984, 259:5526-5530.

6. Ackerman SJ, Bochner BS: Mechanisms of eosinophilia in the pathogenesis of hypereosinophilic disorders. Immunol Allergy Clin North Am 2007, 27:357-375.

7. Lim J, Sternberg A, Manghat N, Ramcharitar S: Hypereosinophilic syndrome masquerading as a myocardial infarction causing decompensated heart failure. BMC Cardiovasc Disord 2013, 13(1):75. Epub ahead of print.

8. Jeon YW, Hong SJ, Kim HJ, Han JP, Kim HK, Ko BM, Park SK, Lee MS: A hypereosinophilic syndrome presenting as eosinophilic colitis. Clin Endosc 2012, 45:444-447.

9. Bansal M, Rai T, Pandey SS: Wells syndrome. Indian Dermatol Online J 2012, 3:187-189.

10. Bogenrieder T, Griese DP, Schiffner R, Büttner R, Riegger GA, Hohenleutner U, Landthaler M: Wells' syndrome associated with idiopathic hypereosinophilic syndrome. Br J Dermatol 1997, 137:978-982.

11. Pagnoux C: Churg-Strauss syndrome: evolving concepts. Discov Med 2010, 9:243-252.

12. Shulman LE: Diffuse fasciitis with hypergammaglobulinemia and eosinophilia: a new syndrome? J Rheumatol 1984, 11:569-570.

13. Lebeaux D, Sène D: Eosinophilic fasciitis (Shulman disease). Best Pract Res Clin Rheumatol 2012, 26:449-458.

14. Cao ZX, Zhao ZF, Zhao XF: Effect of compound glycyrrhizin injection on liver function and cellular immunity of children with infectious mononucleosis complicated liver impairment. Chin J Integr Med 2006, 12:268-272.

\section{doi:10.1186/1746-1596-8-185}

Cite this article as: Li et al:: Recurrent cutaneous necrotizing eosinophilic vasculitis: a case report and review of the literature. Diagnostic Pathology 2013 8:185.

\section{Submit your next manuscript to BioMed Central and take full advantage of:}

- Convenient online submission

- Thorough peer review

- No space constraints or color figure charges

- Immediate publication on acceptance

- Inclusion in PubMed, CAS, Scopus and Google Scholar

- Research which is freely available for redistribution

Submit your manuscript at www.biomedcentral.com/submit 